\title{
Ethics bill prompts second thoughts among scientists
}

Paris. Conservative politicians in the French Senate are pressing for tight restrictions on research using embryos and related aspects of human infertility. But their actions are leading to second thoughts among many who had previously supported demands for a strict legislation to ensure that the research is properly conducted and applied.

In November 1992, a broad political consensus ensured the adoption of France's three bioethics bills after their first reading in the Socialist-led national assembly. The bills were intended as the world's first comprehensive legally-binding code of bioethics, in part reflecting the French tradition of governing professional activity through legislation rather than codes of conduct.

But signs of a rethink by the left came earlier this month when François Mitterrand, the Socialist president who has long championed efforts to legislate on bioethics, said that he is now "unsure that morals could be changed by a law".

In particular, moves by the French Senate to ban research on human embryos and genetic testing before reimplantation have reopened a debate over whether medical progress should be regulated by law or by

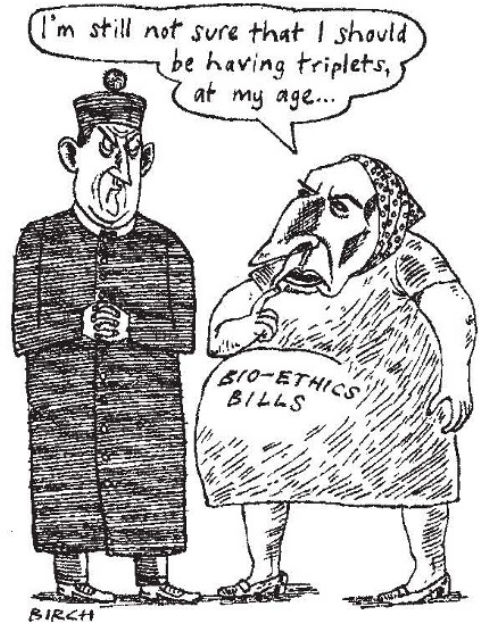

the conscience of individual physicians and researchers.

Many French scientists and physicians are concerned that the conservative-dominated senate will yield to pressure from religious lobbies for further restrictions when it debates the bills in the coming weeks.

Furthermore, the conservative majority that dominates the national assembly since last year's elections will probably endorse the ban on embryo research, and other restrictions, when it gives the bills a final reading in spring. But the government may well oppose the senate's expected proposal to forbid destruction of spare embryos - of which there are around 20,000 in France.
Researchers and physicians generally agree that the bills are both needed and "generally balanced". They also welcome the government's commitment to review legislation in five-year's time.

But many are nonetheless concerned that the latest restrictions, proposed last week by the senate's Commission on Social Affairs, "go too far". Jacqueline Mandelbaum, for example, a researcher at the in vitro fertilization (IVF) centre at the Necker Hospital and the INSERM laboratory on Comparative Human Genetics in Paris, opposes the ban on human embryo research.

She says that such research should improve the viability of embryos used in IVF, as well as the proportion of successful implants. Research on such questions as the mechanisms by which human embryos implant themselves is also needed to improve the understanding of in vivo human reproduction, she argues.

Axel Kahn, director of the INSERM Laboratory of Research on Genetics and Molecular Pathology at the Cochin Institute of Molecular Genetics in Paris, and Jean Dausset, a Nobel prizewinner for medicine, are less convinced of the need for research on human embryos. But both are concerned by the move towards tighter restrictions. Kahn describes the proposed ban on embryo research as "philosophically incoherent", and argues that respecting the "human dignity' of an embryo need not entail banning research on it.

Kahn asks why, if experiments can be done on humans of all ages - including infants - they should not also be allowed on embryos, given the same sort of safeguards. The proposed restrictions on research, he says, are "not very defendable", because they are being made on "ideological and religious grounds".

Dausset, a leading figure in recent debates about the ethics of genetics research, says that much research can be done using animal embryos rather than human ones. But he adds that decisions should still be left to researchers. "If we legislate on everything we will go too far," says Dausset. "We must give a margin of liberty to the conscience of researchers and physicians."

All three researchers say that the proposed ban on preimplantation diagnosis and selection of embryos should allow exceptions. They suggest limiting such techniques to a defined list of serious diseases, and carrying them out at specially authorized centres. Indeed, the state already permits therapeutic abortion of fetuses carrying genetic abnormalities.

One researcher who defends the ban, however, is Jacques Testart, a researcher at

\section{How France plans to legislate for bioethics}

Paris. Three bills concerned with bioethics are being discussed in the French Senate (see left) following their approval by the National Assembly and subsequent amendment by the government. The first, from the Ministry of Justice, aims 'to protect human dignity and the human race'. The bill bans eugenics, but permits gene therapy (providing it is not germline gene therapy). It also bans genetic testing (except for research, medical or judicial purposes), surrogate motherhood and patenting of parts of the human body (including the genome).

The second bill is from the Ministry of Health. This restricts in vitro fertilization (IVF) to living, sterile couples (a male and a female) "of reproductive age", and bans experimental interventions on embryos as well as production of embryos for any use other than IVF (the government has explicitly ruled out IVF for widows and postmenopausal women). The bill also rules that organs cannot be transplanted without explicit consent from donors - or next of kin, if the donor is dead - and that donations must be free and anonymous.

The third bill comes from the Ministry of Research and Higher Education. It amends the data protection act to allow physicians to provide epidemiology researchers with confidential information on patients, providing that patients agree and that their identity is concealed.

D. B.

INSERM's laboratory of Gamete Maturation and Fertilization. Testart argues that the ease of IVF compared with therapeutic abortion means that it could be more readily used to select for sex or other characteristics. But he also agrees that selection of embryos could be permitted in a few well-defined cases.

Testart's main concern is that physicians and researchers could interpret the bills' provisions liberally. He says that the language in the bills - for example, words such as 'sterility', 'serious illness' and 'medically assisted procreation' - is ambiguous in legal terms. Indeed benign neglect of the provisions of the law has co-evolved with the French culture of governing by legislation.

While senators want to protect spare earlystage embryos from destruction, they are holding back from ruling on the status of the embryo. To decide that an eight-celled blastomere, for example, is a person would provide a logical basis for the senate commission's proposed restrictions. But it would create political and social havoc by running into conflict with France's abortion laws.

Declan Butler 